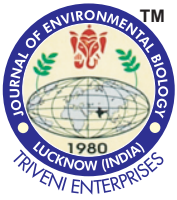

\title{
Relationship between some wild mammals and forest structural diversity parameters
}

\section{Authors Info}

\section{A. Mert* and B. Yalçınkaya}

Department of Wildlife Ecology and Management, Faculty of Forestry, Süleyman Demirel University, Isparta-32260, Turkey

*Corresponding Author Email : ahmetmert@sdu.edu.tr

Key words

Habitat,

Structural diversity,

Wildlife,

Wild mammal

\section{Publication Info}

Paper received : 30.06 .2016

Revised received : 30.05 .2016

Accepted : 26.06.2017

\section{Abstract}

Aim: The forests are most crucial ecosystems that provide opportunities for wildlife species in terms of nutrition and harboring properties. Theoretically, structural heterogeneity of plants in a field assosiated with number of living organisims in there. The main objective of the study was to investigate relationships between distribution of wild animals and variables including height of leafy branches from ground, thickness and density of litter layer, height and density of herb and shrub layer and height and density of tree layer.

Methodology: Sign of wild mammals were inventoried using indirect inventory techniques in seventy sampling plots in Ağlasun (Burdur, Turkey). Height leafy branches from the ground and thickness and density of litter layer, height and density of herb and shrub layers, stone, soil, rock covering landform were measured. To determine relationships between this variables, regression and classification tree technique was applied.

Results: No relationship was found between European hare and Beech marten with forest structural diversity parameters. Distribution of Wild boar (AUC; 0.85), Badger (AUC; 0.81) and Red fox (AUC; 0.85) were affected by some forest structural diversity parameters such as tree densiy, herb density and rock density.

Interpretation: The results revealed that the areas with structural diversity became rich in biodiversity. The increase in fruit trees and plant species diversity contributes to support wildlife, as well. This study is significant for determination of relationship between wild animals and easily measured structural diversity parameters.
Effect of forest structural diversity parameters on habitat preferences of wild mammals

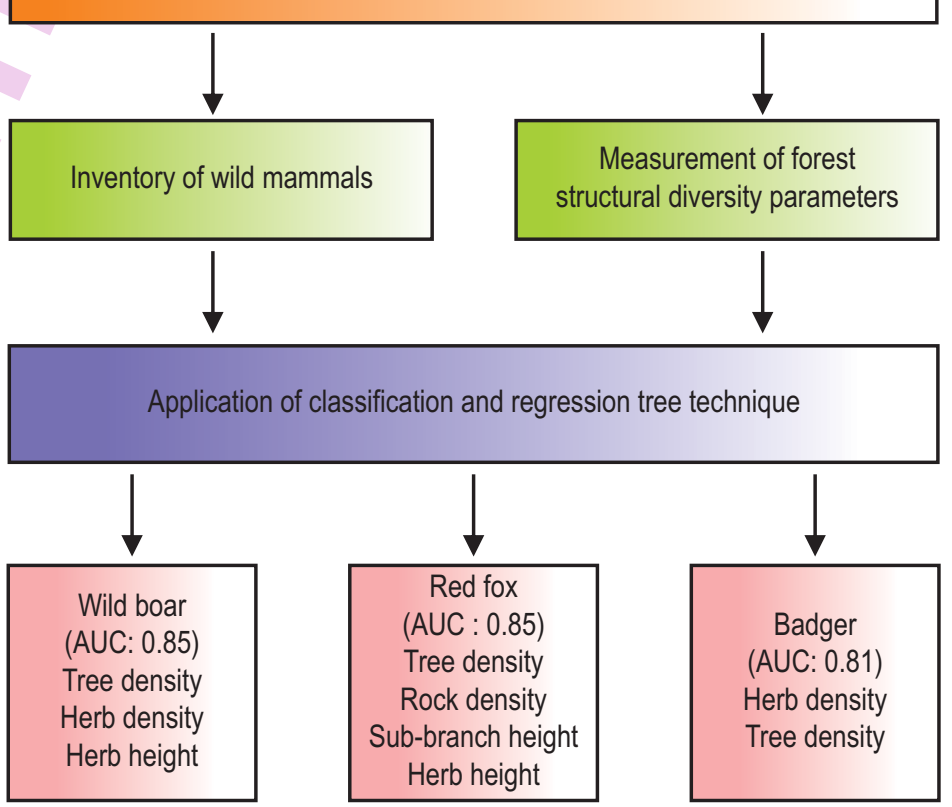




\section{Introduction}

Wildlife resources contribute to many aspects of human well-being such as recreational, ecological, economic, social, cultural and scientific (Wagner, 1989; Taylor and Knight, 2003). But excessive use of these resources leads to a number of problems, which cannot be compensated (Hutchings, 2006).

Recently, the term of species ecology has become quite important due to decreasing number of living organisms around the world. Investigation of the relationships between environmental factors and endangered populations, determination of their habitat properties, and conservation of their habitats are most important to prevent disappearance of wildlife species. Theoretically, forests host a large number of species provided there are stands and other qualified area. So, if structural diversity of forest ecosystems increase, biological diversity rises (Noss, 1990; Ister and Gokbulak, 2009).

Structural diversity of a forest is defined at two different levels i.e., landscape level stand structure and stand level structure (Newton, 2007).At the stand level, structural diversity parameters have been used to promote and protect biodiversity in area since physical structure of the forest is better defined with these parameters (Ozcelik et al., 2008). Therefore, it is accepted that structural diversity values at the stand level are more important than structural diversity values of landscape stand structure (Kuuluvainen et al., 1996; Majumdar and Datta, 2015).

Structural diversity of forest stands is divided into horizontal structure and vertical structure. Horizontal structural diversity is created by canopy, crown structure, distance between trees, different plant types, different form of same kind and their positions relative to each other. Vertical structural diversity is created by tree density, trunk thickness, diversity of tree size and multilayer formed by herbs, shrubs and trees. If the structural sequence of species increases in a specific area,complexity of stand structure increases. And so, area will prosper from the point of biological diversity (Ferreira and Prance, 1999). It has been shown that forest ecosystems which have heterogeneous structure host a larger number of species. Thus, the complexity of the forest structure (as type, and structure) is recognized as a biodiversity indicator (Lindenmayer et al., 2000). Many studies have been conducted to estimate stand or landscape level of forest structural diversity (Özdemir and Karnieli, 2011; Özdemir and Donoghue, 2013).

Plant density, the most important factor on structural diversity, controls light and wind entering into the stand, and its microclimate. It is a substantial habitat component showing change (Betts, 1997). The significant parameters causing change in plant density are global climate change, forest fires, human impact and abandonment of habitats. There is not enough information about our native wild animals are affected by all these changes (Driscoll and Donavan, 2004). As a result of a change that will occur, either native species will keep up with the changes or they will migrate to different area. Otherwise, they will be under risk or may disappear (Holmes and Sherry, 2001).

In most studies, structural diversity composed of plant cover rate has been emphasized as important but it always has been ignored due to difficult measuring. Probably, use of easy measured structural diversity parameters to predict stand structure will help to overcome this problem (Frazer et al., 1999). Habitat structural diversity can be estimated by the way of these easily measured parameters (Mert, 2013). The present study was carried out to investigate the relationships between distribution of wild animals and variables including height of leafy branches from ground, thickness and density of litter layer, height and density of herb and shrub layer and height and density of tree layer.

\section{Materials and Methods}

Site description: Study area is located in Ağlasun-Burdur at Lakes District ( $37^{\circ} 33^{\prime} \mathrm{N}, 30^{\circ} 32^{\prime}$ E, 350-2200 m above sea level) (Fig. 1). The area, surrounded by high mountains, has a specific tough climate and is covered by a forest composed of nearly $52 \%$ pine species. In general, Pinusbrutia Ten., Pinusnigra Arn., Quercus coccifera L. and Juniperus spp. are dominant species in the area.

Sampling method: The study was conducted in 70 sample areas. Field work was carried out in the months May-June. Size of a sample area was taken as $100 \mathrm{~m} \times 100 \mathrm{~m}$; sample areas were selected at random. Presence-absence survey was performed and sign of wild mammals (tracks, scrapes, burrow, footprint and feces) was noted (Baddeley, 1985; Oğurlu, 1996). Also, latitude,

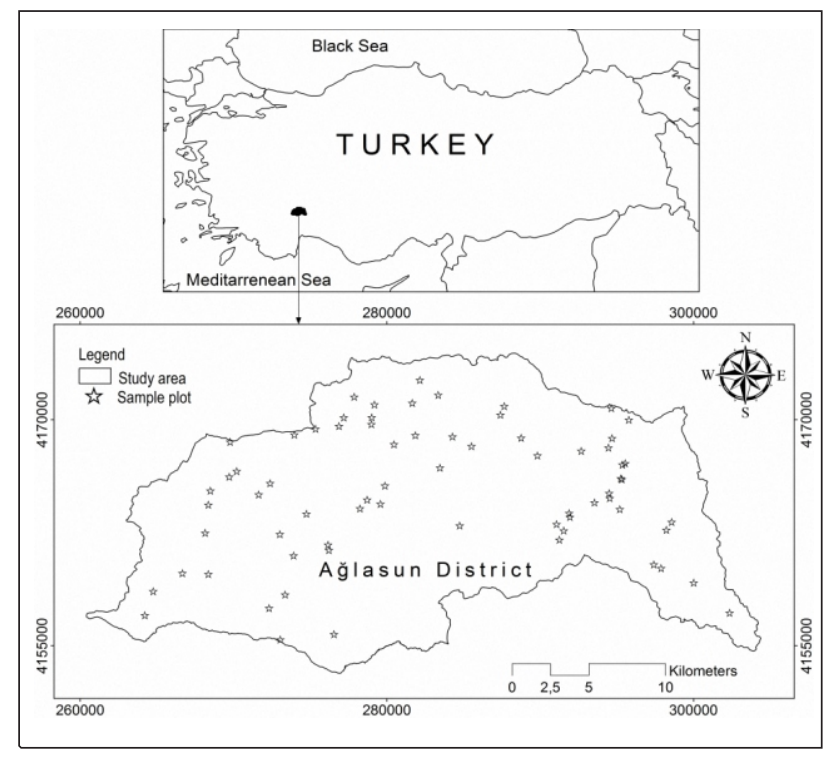

Fig. 1 : Geographical location of study area (Ağlasun-Burdur district) 
longitude, elevation(by GPS), aspect (by compass), slope (by clinometer) variables were recorded for each sample area.

Data analysis: Ecological data are usually complex and do not move along an axis. In other words, relationships between variables are usually not linear (Özkan, 2012). Commonly used statistical models are not enough for determining nonlinear relationships. Classification and regression tree is the most ideal method to put forth these relationships (CART: Breiman et al., 1984). Both categorical and continuous independent variables can be model led with this method. If dependent variable is categorical, method is named as classification tree. But if dependent variable is continuous, method is named as regression tree (Breiman et al., 1984; Özkan and Mert, 2010).

Classification tree method was used to describe relationships between presence-absence data (sign of wild animals in study field) and structural diversity parameters using with Area Under ROC (Receiver Operating Characteristic) Curve (AUC) values. Classification tree gave better results with structural diversity parameters (Mert, 2013). Eighty percent of data was used as training data, while $20 \%$ of the data was used as test data. In addition, correlation analysis was used to examine relation between structural diversity parameters being independent variables(Neumann andStarlinger, 2001; Mertet al., 2016).

\section{Results and Discussion}

As a result of study, sign of five different species, European hare (Lepus europaeus), Wild boar (Susscrofa), Badger (Melesmeles), Beech marten (Martesfoina) and Red fox (Vulpes vulpes) were inventoried in 70 sample areas (Table 1).

Variables showing high correlation with each other leads to multicollinearity problem. For this reason, correlation analysis was carried out to see relationships between easy measurable structural diversity parameters (Table 2).

The relationship between variables having value greater than 0.85 leads to multicollinearity problem (Eymen, 2007). Table 2 does not show easy measurable structural diversity parameters having high correlation ( $>0.85$ ) with each other. Therefore, all parameters were taken into account. ROC values (belonged to classification tree method) is given in Table 3 .
Models obtained for European hare and Beech marten could not be confirmed (Table 3). In short, relationships between these two species and easily measured structural diversity parameters could not be confirmed. Classification tree analysis was performed to examine relationships between easily measured structural diversity parameters and wild animals. Results of tree analysis are given in Fig. 2.

Classification tree for wild boar had 4 terminal nodes. It was found that wild boar preferred tree density $>18.5 \%$. If tree density was under $18.5 \%$, wild boar choos fields with over $45 \%$ of herb density. Also wild boar prefered area herb density under $45 \%$ value in addition to herb height $>22.5 \mathrm{~cm}$. In this context, Oğurlu and Aksan (2013) reported that these areas provide food and harbour need of wild animals is confirms the results of this study.

In a model created for red fox, the tree composed of 5 nodes. Red fox was not seen in area having tree density $>27.5 \%$. If an area had tree density $\leq 27.5$, rate of rock on surface $\leq \% 35$ and sub-branch height $\leq 125 \mathrm{~cm}$ and herb height $>45 \mathrm{~cm}$, red fox prefered this area. These areas were preferred by red fox in terms of prey-predator relation. The present findings are consistent with the study of Diaz-Ruiz et al. (2016). As a result of analysis for badger, tree consisted of four nodes. It was found that these species absolutely prefered areas having herb density $(>17.5 \%)$ and tree $(>27.5 \%)$. Badger selected this area, especially for burrow (Aksanet al., 2014; Mert and Yalçınkaya, 2016).

Examination of relationships between easily measured structural diversity parameters and inventoried species in study area, it shows that tree density and herb density effect distribution of wild animals. Wild animal species prefer areas having different structural diversity for shelter, hide and food requirements (Mert, 2013).

If an area has many plant species and different form and height combination of these species, the area is rich in biological diversity. If the number of different plants in an area increases, herbivore animal species are attracted for food. After a while, with the increase in numbers of herbivore individuals, carnivore species will be attracted. Thus, biodiversity will increase depending on each other. Normally, relationships between structural diversity and wild animals show a change according to

Table 1 : Inventoried animal species in study areas

\begin{tabular}{lccc}
\hline Wild animal species & \multicolumn{2}{c}{ Number of sample areas } & Total number of individuals seen \\
\cline { 2 - 3 } & Presence & Absence & \\
\hline European hare & 41 & 29 & 192 \\
Wild boar & 54 & 16 & 167 \\
Badger & 12 & 58 & 31 \\
Beech marten & 12 & 58 & 21 \\
Red fox & 18 & 52 & 24 \\
\hline
\end{tabular}


Table 2: Correlation analysis of structural diversity variables

\begin{tabular}{|c|c|c|c|c|c|c|c|c|c|c|c|}
\hline & Rock & Soil & $\begin{array}{l}\text { Sub- } \\
\text { branch } \\
\text { height }\end{array}$ & $\begin{array}{l}\text { Herb } \\
\text { height }\end{array}$ & $\begin{array}{l}\text { Herb } \\
\text { density }\end{array}$ & $\begin{array}{l}\text { Shrub } \\
\text { height }\end{array}$ & $\begin{array}{l}\text { Shrub } \\
\text { density }\end{array}$ & $\begin{array}{l}\text { Tree } \\
\text { density }\end{array}$ & $\begin{array}{l}\text { Litter } \\
\text { layer } \\
\text { height }\end{array}$ & $\begin{array}{l}\text { Diameter } \\
\text { class }\end{array}$ & Canopy \\
\hline Stone & -0.07 & -0.68 & -0.26 & -0.13 & -0.01 & 0.07 & 0.08 & -0.25 & -0.02 & -0.18 & -0.31 \\
\hline Rock & & -0.61 & -0.36 & -0.03 & 0.11 & -0.07 & -0.02 & -0.43 & -0.26 & -0.35 & -0.29 \\
\hline Soil & & & 0.47 & 0.16 & -0.05 & -0.01 & -0.04 & 0.47 & 0.20 & 0.33 & 0.46 \\
\hline Sub-branch height & & & & 0.11 & -0.26 & 0.04 & 0.07 & 0.51 & 0.69 & 0.69 & 0.34 \\
\hline Herb height & & & & & 0.23 & 0.11 & -0.06 & -0.05 & 0.08 & 0.05 & -0.05 \\
\hline Herb density & & & & & & -0.15 & -0.49 & -0.35 & -0.27 & -0.36 & -0.26 \\
\hline Shrub height & & & & & & & 0.36 & 0.13 & -0.12 & 0.07 & 0.10 \\
\hline Shrub density & & & & & & & & 0.01 & -0.05 & 0.08 & 0.07 \\
\hline Tree density & & & & & & & & & 0.39 & 0.71 & 0.79 \\
\hline Litter layer height & & & & & & & & & & 0.62 & 0.25 \\
\hline Diameter class & & & & & & & & & & & 0.51 \\
\hline
\end{tabular}

Table 3 : Relationships between wild animals and forest structural diversity parameters

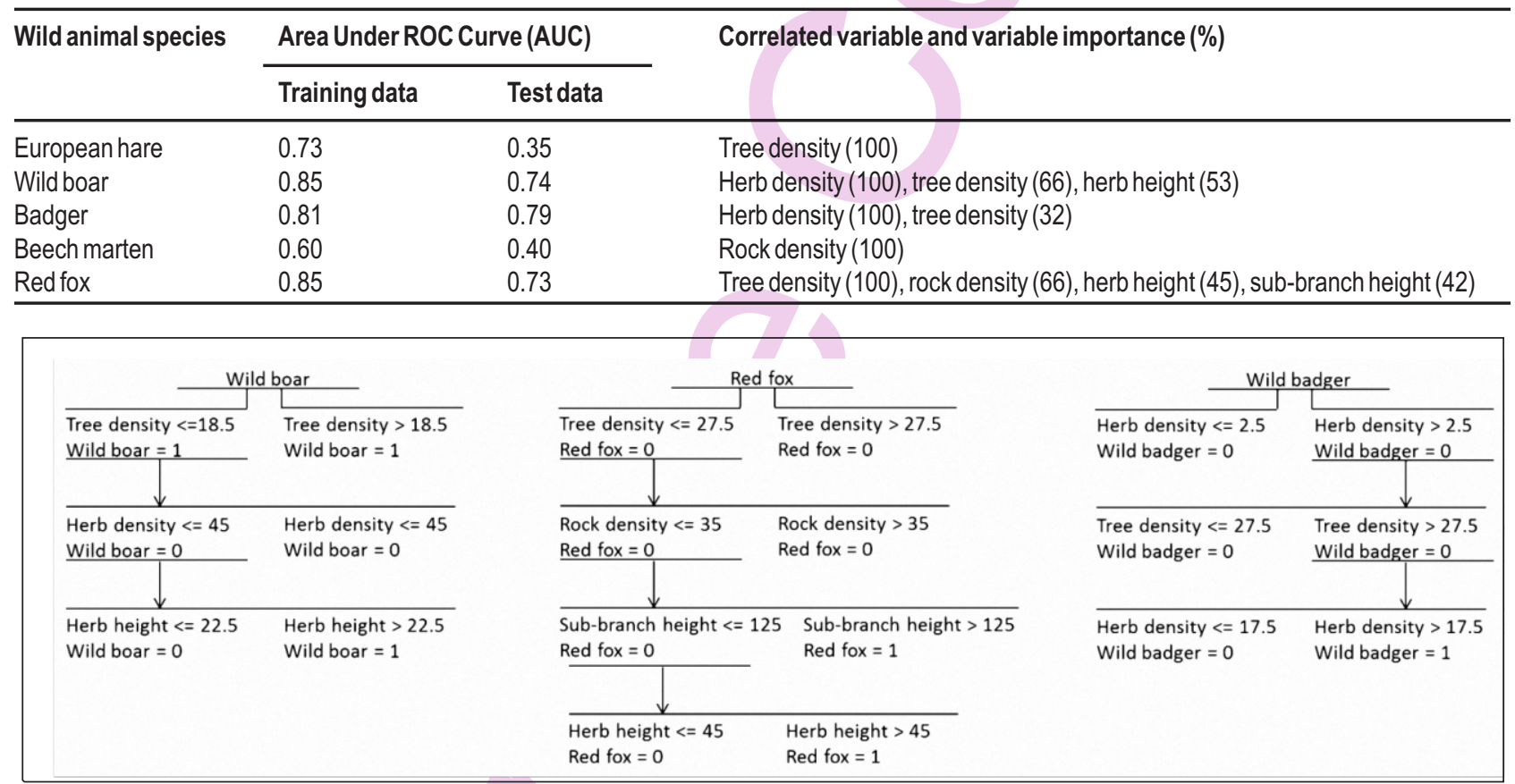

Fig. 2 : Classification-tree model made for wild mammal species

species (sheltering and hiding), but it is known that dense and complex areas are preferred by wild animals (Mysterud and Østbye, 1999; McNeely, 2004). In this connection, edge effect is important, as well. Wild animals choosing this area for shelter and hiding will require open areas at the edge of this area for escape action (Harper et al., 2005). For this reason, prey animals usually choose more complex area. For example; European hare being herbivore chooses herb and shrub rich area for food requirement. They meet the needs of shelter and hiding in area having tree density, height of shrub and herb. Moreover, these species absolutely demand density of soil and high slope.
According to correlation analysis results, it was found that relation of soil density, density of stone and rock was negative at highest importance level (0.01). Relationships between tree density with rock density and herb density were significantly positive (0.01). It is known that if tree density increases, density of herb and shrub decreases because the amount of light entering inside decrease (Pitelka et al., 1980; Guariguata et al., 1995). In general, forests consist of single tree species in Mediterranean Region. Therefore, tree density increasing in area leads to decrease herb and shrub density and structural diversity value. 
When relations of wild boar, badger were easily measured structural diversity parameters were examined, it was found that the most important factor was plant cover. The areas having heavy plant cover provided both food and hide possibility. It was thought that these areas were more preferred by species due to human activity (Wikelski and Cooke, 2006). Red foxes choose areas with lowest tree density and height of herb layer. Open fields having more herb density was preferred by red fox species for shrewmouse, hare, etc.

The results show that the areas with structural diversity become rich in terms of biodiversity. The increase in fruit trees and plant species diversity contributes to support wildlife, as well. This study is significant for determination of relationship between wild animals and easily measured structural diversity parameters. However, these results must be supported with more comprehensive studies including larger area, more sample areas and different easily measured structural diversity parameters.

\section{Acknowledgment}

We thank to project 4123- YL1-14 supported by the Coordination Unit for Scientific Research Projects, Süleyman Demirel University.

\section{References}

Aksan, Ş., I. Özdemir and İ. Oğurlu: Modeling the distributions of some wild mammalian species in Gölcük Natural Park. Biodicon., 7, Turkey (2014).

Baddeley, C.: Assessments of wild animal abundance protection forestry division, Forest Research Institute, 46, New Zealand (1985).

Betts, B.J.: Microclimate in Hell's Canyon mines used by maternity colonies of Myotisyumanensis. J. Mammal, 78, 1240-1250 (1997).

Breiman, L., J. Friedman, C.J. Stone and R. A. Olshen: Classification and regression trees. CRC Press (1984).

Diaz-Ruiz, F., J. Caro, M. Delibes-Mateos, B. Arroyo and P. Ferreras: Drivers of red fox (Vulpes vulpes) daily activity: prey availability, human disturbance or habitat structure?.J. Zool., 298, 128-138, (2016).

Driscoll, M.J. and T.M. Donovan: Landscape context moderates edge effects: nesting success of wood thrushes in Central New York. Conserv. Biol., 18, 1330-1338 (2004).

Eymen, E. U.: SPSS 15.0 Veri analiz yöntemleri (Data Analysis Methods). http:// yunus.hacettepe.edu.tr/ tonta/courses/spring 2009/ bby606/ SPSS_15.0_ile_Veri_Analizi.pdf. Date accessed: 03.04.2016 (2007).

Ferreira, L.V. and G.V. Prance: Ecosystem recovery in terra firme forests after cutting and burning: A comparison on species richness, floristic composition and forest structure in the Jau National Park, Amazonia. Bot. J. Linn. Soc., 130, 97-110 (1999).

Frazer, G.W., C.D. Canham and K.P. Lertzman: Gap light analyzer (GLA), Version 2.0: Imaging software to extract canopy structure and gap light transmission indices from true-colour fisheye photographs, user's manual and program documentation. Simon Fraser University, Burnaby, British Columbia, and the Institute of Ecosystem Studies, Millbrook, New York, 36 (1999).

Guariguata, M.R., R. Rheingans and F. Montagnini: Early woody invasion under tree plantations in Costa Rica: implications for forest restoration. Restoration Ecol., 3, 252-260 (1995).

Harper, K.A., S.E. Macdonald, P.J. Burton, J. Chen, K.D. Brosofske, S.C. Saunders and P.A. Esseen: Edge influence on forest structure and composition in fragmented landscapes. Conserv. Biol., 19, 768$782(2005)$

Holmes, R.T. and T.W. Sherry: Thirty-year bird population trends in an unfragmented temperate deciduous forest: importance of habitat change. The Auk, 118, 589-609(2001).

Hutchings, M.R.: Wild mammals and the human food chain. Anim. Sci., 82, 765-766 (2006)

Ister, S.I. and F. Gokbulak: Effect of stand types on understory vegetation. J. Environ. Biol., 30, 595-600 (2009).

Kuuluvainen T., A. Penttinen, K. Leinonen and M. Nygren: Statistical opportunities for comparing stand structural heterogeneity in managed and primeval forests: an example from boreal spruce forest in southern Finland, 30, 315-328 (1996).

Lindenmayer, D.B., C.R. Margules and D.B. Botkin: Indicators of biodiversity for ecologically sustainable forest management. Conserv. Biol., 14, 941-950 (2000).

Majumdar, K. and B.K. Datta: Vegetation types, dominant compositions, woody plant diversity and stand structure in Trishna wildlife sanctuary of northeast India. J. Environ. Biol.,36, 409 (2015).

McNeely, J.A.: Nature vs. nurture: managing relationships between forests, agroforestry and wild biodiversity. Agroforest Syst., 61, 155-165 (2004).

Mert, A. and B. Yalçınkaya: The relation of edge effect on some wild mammals in Burdur-Ağlasun (Turkey) district. Biodicon., 9, 193201 (2016).

Mert, A., Ş. Aksan, U.Y. Özkan and İ. Özdemir : Landsat-8 OLI uydu görüntüsünden çıkarılan arazi çeşitliliği ile kuş türü zenginliği arasındaki ilişkiler. (Relationships between the richness of bird species and structural diversity from satellite images of Landsat-8 OLI). J. Forest.,17, 68-72 (2016).

Mysterud, A. and E. Østbye: Cover as a habitat element for temperate ungulates: Effects on habitat selection and demography. Wildlife Soc. B., 27, 385-394 (1999).

Neumann, M. and F. Starlinger: The significance of different indices for stand structure and diversity in forests. Forest Ecol. Manag., 145 91-106 (2001).

Newton, A.C.: Forest Ecology and Conservation: A handbook of techniques. Oxford University Press. Oxford, 454 (2007).

Noss, R.F.: Indicators for monitoring biodiversity: A hierarchical approach, Conserv.Biol.,4, 355-364 (1990).

Oğurlu, İ.: Geyiklerde popülasyon tahmin ve metotlari ve dışkı sayım tekniklerinin gelişmesi (Population estimation and methods in deer and development of fecal counting techniques). Doğa Türk Zooloji Dergisi, 20, 307-317 (1996).

Oğurlu, İ. and Ş. Aksan : Bazı memeli yaban hayvanlarının potansiyel habitatları için gösterge odunsu bitki türlerinin belirlenmesi (Determination of indicator woody plant species for potential habitats of some wild mammalian species).Turk. J. For.,14, 81-87 (2013).

Ozcelik, R., A.U. Gul, J. Merganic and K. Merganicova: Tree species diversity and its relationship to stand parameters and geomorphology features in the eastern Black sea region forests of Turkey. J. Environ. Biol., 29, 291 (2008).

Ozdemir, I. and A. Karneili: Predicting forest structural parameters using the image texture derived from World View-2 multispectral imagery 
in a dryland forest, Israel. Intl. J. App. Earth Observ. Geoinform., 13, 701-710, (2011).

Ozdemir, İ. and D.N.M. Donoghue: Modelling tree size diversity from airborne laser scanning using canopy height models with image texture measures. Forest Ecol. Manag., 295, 28-37, (2013).

Özkan, K.: Modelling ecological data using classification and regression tree technique (CART). Fac. Fore. J., 13, 1-4 (2012).

Özkan, K. and A. Mert : Isparta Yukarı Gökdere yöresinde Kasnak Meşe'sinin senaryolarına göre 2050 ve 2080 yıllarında muhtemel potansiyel yayııı̧ alanlarının coğrafi modellemesi (Possible potantial distribution areas of the Kasnak Oak (QuercusvulcanicaBoiss. and Heldr. Ex. Kotschy.) according to A2 and B2 scenarios of SRES-IPCC for 2050 and 2080 in the Yukarı Gökdere), Symposium on Combating Desertification, 17-18 Haziran, 2010, Anittaotel, Çorum (2010).

Pitelka, L.F., D.S. Stanton and M.O. Peckenham: Effects of light and density on resource allocation in a forest herb, Aster acuminatus (Compositae). Am. J. Bot.,67, 942-948 (1980).

Taylor, A.R. and R.L. Knight: Wildlife responses to recreation and associated visitor perceptions. Ecol. Appl., 13, 951-963 (2003).

Wagner, F.H.: American wildlife management at the crossroads. Wildl. Soc. Bull.(1973-2006), 17, 354-360 (1989).

Wikelski, M. and S.J. Cooke: Conservation physiology. Trends Ecol. Evol., 21, 38-46 (2006). 